Article

\title{
Oxidative Additon of Tin Thiolates Yielding New Pt-Sn Heterobimetallic Complexes
}

\author{
Rodrigo Herbert $\mathrm{Vaz}^{a}$, Anuar Abras ${ }^{b}$, and Rosalice Mendonça Silva ${ }^{* a}$ \\ ${ }^{a}$ Depto. de Química, Universidade Federal de Minas Gerais, \\ 31270-901 Belo Horizonte - MG, Brazil \\ ${ }^{b}$ Depto. de Física, Universidade Federal de Minas Gerais,
} 31270-901 Belo Horizonte - MG, Brazil

Received: April 18, 1997

\begin{abstract}
Foram estudadas as reações entre $\mathrm{CODPtCl}_{2}, \mathrm{COD}=1,5$ ciclooctadieno, e os compostos tiolato de estanho $(\mathrm{Ph})_{3} \mathrm{Sn}(\mathrm{SPh})$ e $(\mathrm{Ph})_{2} \mathrm{Sn}(\mathrm{SPh})_{2}$. Reação entre $\mathrm{CODPtCl}_{2}$ e $(\mathrm{Ph})_{3} \mathrm{Sn}(\mathrm{SPh})$ originou dois novos complexos heterobimetálicos contendo $\mathrm{Pt}$ e $\mathrm{Sn}$, dependendo da razão molar $\mathrm{CODPtCl}_{2} /(\mathrm{Ph})_{3} \mathrm{Sn}(\mathrm{SPh})$. Para uma razão molar de 1: 2 foi obtido $\mathrm{CODPt}(\mathrm{SPh})_{2}(\mathrm{Cl}) \mathrm{Sn}(\mathrm{Ph})_{3} .2 \mathrm{CH}_{2}$ $\mathrm{Cl}_{2}$, complexo 1, juntamente com o complexo homometálico $\mathrm{CODPt}(\mathrm{SPh}) \mathrm{Cl}_{\mathrm{CH}} \mathrm{Cl}_{2}$. Para a razão molar 1:1 o complexo formado foi $\mathrm{CODPt}(\mathrm{SPh})(\mathrm{Cl})_{2} \mathrm{Sn}(\mathrm{Ph})_{3} \cdot 3 \mathrm{CH}_{2} \mathrm{Cl}_{2}$, complexo 2. Reação com $(\mathrm{Ph})_{2} \mathrm{Sn}(\mathrm{SPh})_{2}$ não originou nenhum complexo heterobimetálico, apenas $\mathrm{CODPt}(\mathrm{SPh})_{2} .{ }_{4} \mathrm{CH}_{2} \mathrm{Cl}_{2}$. Os complexos foram caracterizados por espectroscopias Mössbauer, de IV, RMN de ${ }^{1} \mathrm{H},{ }^{13} \mathrm{C},{ }^{195} \mathrm{Pt}$, ${ }^{119} \mathrm{Sn}$, análise elementar e absorção atômica.

The reactions between $\mathrm{CODPtCl}_{2}, \mathrm{COD}=1,5$ cyclooctadiene, and the tin thiolate compounds $(\mathrm{Ph})_{3} \mathrm{Sn}(\mathrm{SPh})$ and $(\mathrm{Ph})_{2} \mathrm{Sn}(\mathrm{SPh})_{2}$ have been studied. Reaction between $\mathrm{CODPtCl}_{2}$ and $(\mathrm{Ph})_{3} \mathrm{Sn}(\mathrm{SPh})$ yielded two new Pt-Sn heterobimetallic complexes depending on the $\mathrm{CODPtCl}_{2} /(\mathrm{Ph})_{3} \mathrm{Sn}(\mathrm{SPh})$ molar ratio. For a 1:2 molar ratio, $\mathrm{CODPt}(\mathrm{SPh})_{2}(\mathrm{Cl}) \mathrm{Sn}(\mathrm{Ph})_{3} .2 \mathrm{CH}_{2} \mathrm{Cl}_{2}$, complex 1, was obtained, together with the homometallic complex $\mathrm{CODPt}(\mathrm{SPh}) \mathrm{Cl}_{2} \mathrm{CH}_{2} \mathrm{Cl}_{2}$. For a 1:1 molar ratio the complex formed was $\mathrm{CODPt}(\mathrm{SPh})(\mathrm{Cl})_{2} \mathrm{Sn}(\mathrm{Ph})_{3} \cdot 3 \mathrm{CH}_{2} \mathrm{Cl}_{2}$, complex 2. Reaction with $(\mathrm{Ph})_{2} \mathrm{Sn}(\mathrm{SPh})_{2}$ did not yielded any heterobimetallic complex, but rather $\mathrm{CODPt}(\mathrm{SPh})_{2} \cdot 4 \mathrm{CH}_{2} \mathrm{Cl}_{2}$. The complexes were characterized by IR, ${ }^{1} \mathrm{H}-\mathrm{NMR},{ }^{13} \mathrm{C}-\mathrm{NMR},{ }^{195} \mathrm{Pt}-\mathrm{NMR},{ }^{119} \mathrm{Sn}-\mathrm{NMR}$ and Mössabauer spectroscopies, elemental analysis and atomic absorption.
\end{abstract}

Keywords: tin thiolates, oxidative addition, Pt-Sn heterobimetallics

\section{Introduction}

We have been using thiolate compounds of tin, a main group metal, to react with niobium compounds to obtain heterobimetallic complexes. Reaction between $\left(\eta^{5}-\right.$ $\left.\mathrm{C}_{5} \mathrm{H}_{5}\right)_{2} \mathrm{NbCl}_{2}$ and $(\mathrm{Ph})_{3} \mathrm{Sn}(\mathrm{SPh})$ yielded a heterobimetallic complex bridged by a sulfur atom, instead of the thiolate ligand, due to a $\mathrm{C}-\mathrm{S}$ bond cleavage ${ }^{1}$. Bis(thiolato) complexes of titanium, an early transition metal like niobium, are known to react with halide complexes of platinum, a late transition metal, yielding thiolate complexes, both terminal or bridging, but none with a sulfur atom, no C-S bond cleavage was reported ${ }^{2}$. One aspect that seemed important to verify was whether reaction between platinum and thiolate compounds of tin would activate C-S bonds. There also existed the possibility that a heterobimetallic complex could be formed as in the case with niobium ${ }^{1}$. In this paper we report the results obtained from reactions between $\mathrm{CODPtCl}_{2}$ and the tin compounds $(\mathrm{Ph})_{3} \mathrm{Sn}(\mathrm{SPh})$ and $(\mathrm{Ph})_{2} \mathrm{Sn}(\mathrm{SPh})_{2}$, yielding the complexes $\mathrm{CODPt}(\mathrm{SPh})_{2}$ (Cl) $\mathrm{Sn}(\mathrm{Ph})_{3} .2 \mathrm{CH}_{2} \mathrm{Cl}_{2}$, complex 1, CODPt $(\mathrm{Cl})_{2}(\mathrm{SPh}) \mathrm{Sn}$ (Ph)3.3 $\mathrm{CH}_{2} \mathrm{Cl}_{2}$, complex 2, products of oxidative addition reactions, as well as $\mathrm{CODPt}(\mathrm{SPh})(\mathrm{Cl}) \cdot \mathrm{CH}_{2} \mathrm{Cl}_{2}$, complex $\mathbf{3}$, and $\mathrm{CODPt}(\mathrm{SPh})_{2} .4 \mathrm{CH}_{2} \mathrm{Cl}_{2}$, complex 4. 


\section{Experimental}

\section{General comments}

All operations were carried out under pure dinitrogen, using Schlenk and vacuum techniques. Nitrogen was predried over an in line columm consisting of molecular sieves, calcium chloride and calcium sulfate. Dichloromethane was distilled from calcium hydride, pentane and hexane from sodium/benzophenone and petroleum ether was left over molecular sieves before being used. All solvents were used immediately following distillation or stored under nitrogen over the appropriate molecular sieves. $\mathrm{CODPtCl} 2,(\mathrm{Ph})_{3} \mathrm{Sn}(\mathrm{SPh})$ and $(\mathrm{Ph})_{2} \mathrm{Sn}(\mathrm{SPh})_{2}$ were prepared according to literature procedures ${ }^{3,4}$. ${ }^{119} \mathrm{Sn}$ Mössbauer spectroscopy was performed in a constant acceleration equipment moving a $\mathrm{CaSnO}_{3}$ source at room temperature. The samples were measured at liquid nitrogen temperature. All spectra were computer-fitted assuming Lorentzian lineshapes. Infrared spectra were recorded on a Perkin-Elmer 283B spectrophotometer in the range 4000$200 \mathrm{~cm}^{-1}$, in CsI pellets. ${ }^{1} \mathrm{H}-,{ }^{13} \mathrm{C}-,{ }^{195} \mathrm{Pt}-$ and ${ }^{119} \mathrm{Sn}-\mathrm{NMR}$ spectra were recorded on a Bruker AC-400 and referenced to internal $\mathrm{SiMe}_{4}$. $\mathrm{C}$ and $\mathrm{H}$ analyses were performed using a Perkin-Elmer PE-2400 CHN microanalyser. Atomic absorption for platinum and tin was performed on a Hitachi Z-8200 Polarized Zeeman Atomic Absorption Spectrophotometer.

Reaction between $\mathrm{CODPtCl}_{2}$ and $(\mathrm{Ph})_{3} \mathrm{Sn}(\mathrm{SPh})$ : a$200 \mathrm{mg}(0.534 \mathrm{mmol})$ of $\mathrm{CODPtCl}_{2}$ were put to react with $490 \mathrm{mg}(1.07 \mathrm{mmol})$ of $(\mathrm{Ph})_{3} \mathrm{Sn}(\mathrm{SPh})$, in $\mathrm{CH}_{2} \mathrm{Cl}_{2}$, under reflux. Immediatelly after the addition of the solvent the reaction color turned to yellow. After two hours of reaction the solvent was removed under vacum leaving a yellow residue that was washed three times with petroleum ether. The solvent separated and a white solid precipitated, $(\mathrm{Ph})_{3} \mathrm{SnCl}$. The yellow residue was redissolved in dichloromethane and upon addtion of hexane $(\mathrm{COD})(\mathrm{SPh})_{2}$ ClPtSn $(\mathrm{Ph})_{3} \cdot 2 \mathrm{CH}_{2} \mathrm{Cl}_{2}$, complex 1, precipitated as a yellow solid. Yield: $49.4 \%$. The mother liquor was separated and submitted to the same procedure from which (COD)Pt $(\mathrm{SPh}) \mathrm{Cl} \mathrm{CH}_{2} \mathrm{Cl}_{2}$, complex 3, was obtained. Yield: $8.36 \%$. $(\mathrm{Ph})_{3} \mathrm{SnCl}$ was characterized by comparision of the m.p, IR, Mössbauer data and ${ }^{1} \mathrm{H}-\mathrm{NMR}$ of an authentic sample. $(\mathrm{COD})(\mathrm{SPh})_{2} \mathrm{ClPtSn}(\mathrm{Ph})_{3} .2 \mathrm{CH}_{2} \mathrm{Cl}_{2}$ : Anal. Calc. for $\mathrm{C}_{45} \mathrm{H}_{41}$ $\mathrm{S}_{2} \mathrm{Cl}_{5} \mathrm{PtSn}$ (found): $\mathrm{C}=44.58$ (44.55), $\mathrm{H}=3.80$ (3.81), $\mathrm{Pt}=$ 18.11(20.69). IR ( $\left.\mathrm{cm}^{-1}, \mathrm{CsI}\right): 3050,3040,3000,2940$, $1570,1470,1430,1410,1060,1050,1005,980,715,670$, $660,455,420,305,300,235 ;{ }^{1} \mathrm{H}-\mathrm{NMR}\left(\delta, \mathrm{CDCl}_{3}\right): 7.68-$ $7.44\left(\mathrm{~m}, 25 \mathrm{H}, 5 \mathrm{C}_{6} \mathrm{H}_{5}\right), 5.60\left(\mathrm{br}, 4 \mathrm{H}, \mathrm{CH}=\mathrm{CH},{ }^{2} \mathrm{~J}_{\mathrm{Pt}-\mathrm{H}}=67.89\right.$ $\mathrm{Hz}), 2.68-2.37\left(\mathrm{~m}, 8 \mathrm{H}, \mathrm{CH}_{2}\right) ;{ }^{13} \mathrm{C}-\mathrm{NMR}\left(\delta, \mathrm{CDCl}_{3}\right)$ : 137.31, 136.12, 130.46, 129.14 (aromatics), $99.98(\mathrm{CH}$, JPt-C not observed), $30.88\left(\mathrm{CH}_{2}\right) ;{ }^{119} \mathrm{Sn}-\mathrm{NMR}\left(\delta, \mathrm{CDCl}_{3}\right)$ : $-50.85 ;{ }^{195} \mathrm{Pt}-\mathrm{NMR}\left(\delta, \mathrm{CDCl}_{3}\right)$ : -3834.8 ; Mössbauer: $(\mathrm{mm} / \mathrm{s}): \delta=1.34 \pm 0.02$ and $\Delta=2.54 \pm 0.01$. (COD) $\mathrm{Pt}(\mathrm{SPh})(\mathrm{Cl}) \cdot \mathrm{CH}_{2} \mathrm{Cl}_{2}$ : Anal. Calc. for $\mathrm{C}_{15} \mathrm{H}_{19} \mathrm{SCl}_{3} \mathrm{Pt}$ (found): $\mathrm{C}=35.80$ (36.86), $\mathrm{H}=3.48$ (2.79); IR ( $\left.\mathrm{cm}^{-1}, \mathrm{CsI}\right)$ : $3080,3070,3015,3005,2980,1590,1480,1020,1000$, $725,670,470,430,315,220 ;{ }^{1} \mathrm{H}-\mathrm{NMR}\left(\delta, \mathrm{CDCl}_{3}\right): 7.70-$ $7.10\left(\mathrm{~m}, 5 \mathrm{H}, \mathrm{C}_{6} \mathrm{H}_{5}\right), 5.63\left(\mathrm{br}, 4 \mathrm{H},{ }^{2} \mathrm{~J}_{\mathrm{Pt}-\mathrm{H}}=66.41 \mathrm{~Hz}\right)$, 2.71-2.25 (m, 8H, $\left.\mathrm{CH}_{2}\right) ;{ }^{13} \mathrm{C}-\mathrm{NMR}\left(\delta, \mathrm{CDCl}_{3}\right): 136.41$, $130.88,129.55,126.28$ (aromatics), $100.45\left(\mathrm{CH}, \mathrm{J}_{\mathrm{Pt}-\mathrm{C}}=\right.$ $600.8 \mathrm{~Hz}), 31.31\left(\mathrm{CH}_{2}\right)$.

b- The reaction described in a was repeated using a 1 : 1 molar ratio of the reactants, $0.544 \mathrm{mmol}$ of each, under room temperature. After a few minutes of reaction a yellow solid started to precipitate. The reaction was left stirring for one hour. After this time the solvent was removed under reduced pressure leaving a yellow residue that was first washed three times with hexane and then dissolved in acetone. Upon addition of hexane a yellow solid precipitated, $\mathrm{COD}(\mathrm{SPh})(\mathrm{Cl})_{2} \mathrm{PtSn}(\mathrm{Ph})_{3} \cdot 3 \mathrm{CH}_{2} \mathrm{Cl}_{2}$, complex 2. Yield: $25 \%$. Anal. Calc. for $\mathrm{C}_{35} \mathrm{H}_{38} \mathrm{SCl}_{8} \mathrm{PtSn}$ (found): $\mathrm{C}=$ 38.88(38.37), $\mathrm{H}=3.49$ (3.07); IR ( $\left.\mathrm{cm}^{-1}, \mathrm{CsI}\right): 3150,2995$, $2925,2900,2860,2815,1570,1460,1430,1335,1325$, $1300,1230,1220,1210,1155,1070,1050,1005,980,895$, $850,800,780,715,680,670,475,440,415,305,285,240$; ${ }^{1} \mathrm{H}-\mathrm{NMR}\left(\delta,\left(\mathrm{CD}_{3}\right)_{2} \mathrm{CO}\right): 7.47-7.22\left(\mathrm{~m}, 4 \mathrm{C}_{6} \mathrm{H}_{5}\right), 5.50$ and $5.37\left(\mathrm{~m}, 4 \mathrm{H}, 2 \mathrm{CH}=\mathrm{CH},{ }^{2} \mathrm{~J}_{\mathrm{Pt}-\mathrm{H}}=58.49\right.$ and $\left.54.14 \mathrm{~Hz}\right), 2.81-$ $2.16\left(\mathrm{~m}, 8 \mathrm{H}, \mathrm{CH}_{2}\right) ;{ }^{13} \mathrm{C}-\mathrm{NMR}\left(\delta,\left(\mathrm{CD}_{3}\right)_{2} \mathrm{CO}\right): 136.82$, $129.15,128.80,127.87$ (aromatics), 105.07, 101.65, $100.21,95.81\left(\mathrm{CH}, \mathrm{J}_{\mathrm{Pt}-\mathrm{C}}\right.$ not observed), 31.57, $31.42\left(\mathrm{CH}_{2}\right)$. ${ }^{195} \mathrm{Pt}\left(\delta,\left(\mathrm{CD}_{3}\right)_{2} \mathrm{CO}\right)=-3653.05$; Mössbauer $(\mathrm{mm} / \mathrm{s}): \delta=$ $1.44 \pm 0.02$ and $\Delta=2.44 \pm 0.05$.

Recation between $\mathrm{CODPtCl}_{2}$ and $(\mathrm{Ph})_{2} \mathbf{S n}(\mathrm{SPh})_{2}$ : a$160 \mathrm{mg}(0.427 \mathrm{mmol})$ of $\mathrm{CODPtCl}_{2}$ and $430 \mathrm{mg}(0.880$ $\mathrm{mmol})$ of $(\mathrm{Ph})_{2} \mathrm{Sn}(\mathrm{SPh})_{2}$ were put to react under room temperature, in $\mathrm{CH}_{2} \mathrm{Cl}_{2}$, for $20 \mathrm{~min}$. After this time the solvent was removed under reduced pressure leaving a yellow residue. This residue was washed three times with petroleum ether, yielding small amounts of a white solid. The yellow residue was redissolved in $\mathrm{CH}_{2} \mathrm{Cl}_{2}$ and upon addition of hexane $\mathrm{CODPt}(\mathrm{SPh})_{2} .4 \mathrm{CH}_{2} \mathrm{Cl}_{2}$, complex 4, precipitated as a yellow solid. Yield: $75 \%$. Anal. Calc. for $\mathrm{C}_{28} \mathrm{H}_{30} \mathrm{~S}_{2} \mathrm{Cl}_{8} \mathrm{Pt}$ (found): $\mathrm{C}=36.96$ (34.07), $\mathrm{H}=3.30$ (2.14); IR ( $\left.\mathrm{cm}^{-1}, \mathrm{CsI}\right): 3080,3060,2960,2890,2840,1590,1470$, 1440, 735, 690, 680, 490, 470, 455, 305, 290; ${ }^{1} \mathrm{H}-\mathrm{NMR}(\delta$, $\left.\mathrm{CDCl}_{3}\right): 7.55-7.13\left(\mathrm{~m}, 10 \mathrm{H}, 2 \mathrm{C}_{6} \mathrm{H}_{5}\right), 4.66(\mathrm{br}, 4 \mathrm{H}, \mathrm{CH}$, $\left.{ }^{2} \mathrm{~J}_{\mathrm{Pt}-\mathrm{H}}=55.64 \mathrm{~Hz}\right), 2.52-2.09\left(\mathrm{~m}, \mathrm{H}, \mathrm{CH}_{2}\right) ;{ }^{13} \mathrm{C}-\mathrm{NMR}(\delta$, $\mathrm{CDCl}_{3}$ ): 136.16, 135.81; 128.09; 126.83; (aromatics), $98.86\left(\mathrm{CH}, \mathrm{J}_{\mathrm{Pt}-\mathrm{C}}=481.60 \mathrm{~Hz}\right), 30.27\left(\mathrm{CH}_{2}\right)$. Yield: $75 \%$.

b- The reaction described in a was repeated using a 1 : 1 molar ratio of the reactants, $0.427 \mathrm{mmol}$ of each, at room temperature. After a few minutes of reaction a yellow solid started to precipitate. The reaction was left stirring for 30 $\mathrm{min}$. After this time the solvent was removed under reduced pressure leaving a yellow residue that was first washed 
three times with hexane and then dissolved in acetone. Upon addition of hexane complex 4 precipitated.

\section{Results and Discussion}

Reaction between $\mathrm{CODPtCl}_{2}, \mathrm{COD}=1,5$ cyclooctadiene, and $(\mathrm{Ph})_{3} \mathrm{Sn}(\mathrm{SPh})$, yielded two different heterobimetallic complexes depending on the $\mathrm{CODPtCl}_{2}$ / $(\mathrm{Ph})_{3} \mathrm{Sn}(\mathrm{SPh})$ molar ratio. For a 1:2 molar ratio complex 1 was obtained and for a 1:1 molar ratio complex 2 was obtained. Together with complex 1, a homometallic complex, complex 3, was obtained in minor amounts. Reaction of $\mathrm{CODPtCl}_{2}$ with $(\mathrm{Ph})_{2} \mathrm{Sn}(\mathrm{SPh})_{2}$ yielded a homometallic complex, complex 4, Fig. 1; irrespective of the reagent molar ratio, no heterometallic complex was obtained. All the complexes were yellow and air stable.

Important IR data for the complexes are shown in Table 1. For complexes $\mathbf{1}$ and $\mathbf{3}$ the $v_{\mathrm{Pt}-\mathrm{S}}$ were observed as a doublet $^{5}$. For complex 1 this is indicative of the cis position of the two thiolate ligands. The same is true for complex 2 regarding the two observed $v_{\mathrm{Pt}-\mathrm{Cl}}$ streching frequencies ${ }^{6}$.

Figure 2 showns the ${ }^{1} \mathrm{H}-\mathrm{NMR}$ spectra of complex 1 . The signal due to the olefinic portion of the COD ligand was observed as a broad singlet together with the Pt satellites. The values of the ${ }^{2} \mathrm{~J}_{\mathrm{Pt}-\mathrm{H}}$ coupling constants are given in Table 2.

For complex 2, two of these coupling constants could be observed which is in accordance with the fact that the - $\mathrm{SPh}$ ligand and one of the $\mathrm{Cl}^{-}$ligands are cis to each other, exerting different trans influences on the $\mathrm{CH}=\mathrm{CH}$ portion of the COD ligand. The resonance of the hydrogens of the olefin is observed as a multiplet, indicating that they are not equivalent. It is worth mentioning that although complex 4 is used as a starting material in the reactions of bis(thio-

Table 1. Characteristic IR data $\left(\mathrm{cm}^{-1}, \mathrm{CsI}\right)$ for complexes 1 to 4 .

\begin{tabular}{lccc}
\hline \multicolumn{1}{c}{ Complex } & $v_{\mathrm{C}_{6} \mathrm{H}_{5}}$ & $v_{\mathrm{Pt}-\mathrm{S}}$ & $v_{\mathrm{Pt}-\mathrm{Cl}}$ \\
\hline $\mathbf{1}$ & 1570 & 300,305 & 235 \\
$\mathbf{2}$ & 1570 & 305 & 240,285 \\
$\mathbf{3}$ & 1590 & 315 & 220 \\
$\mathbf{4}$ & 1590 & 290,305 & - \\
\hline
\end{tabular}

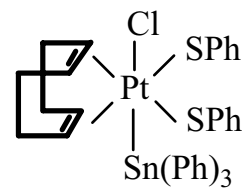

Complex 1

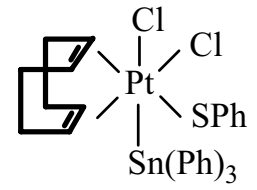

Complex 2 lato)titanocene with (COD) $\mathrm{PtCl}_{2}{ }^{2}$ no spectroscopic data or elemental analysis was reported for $\mathbf{4}$ and we did not find

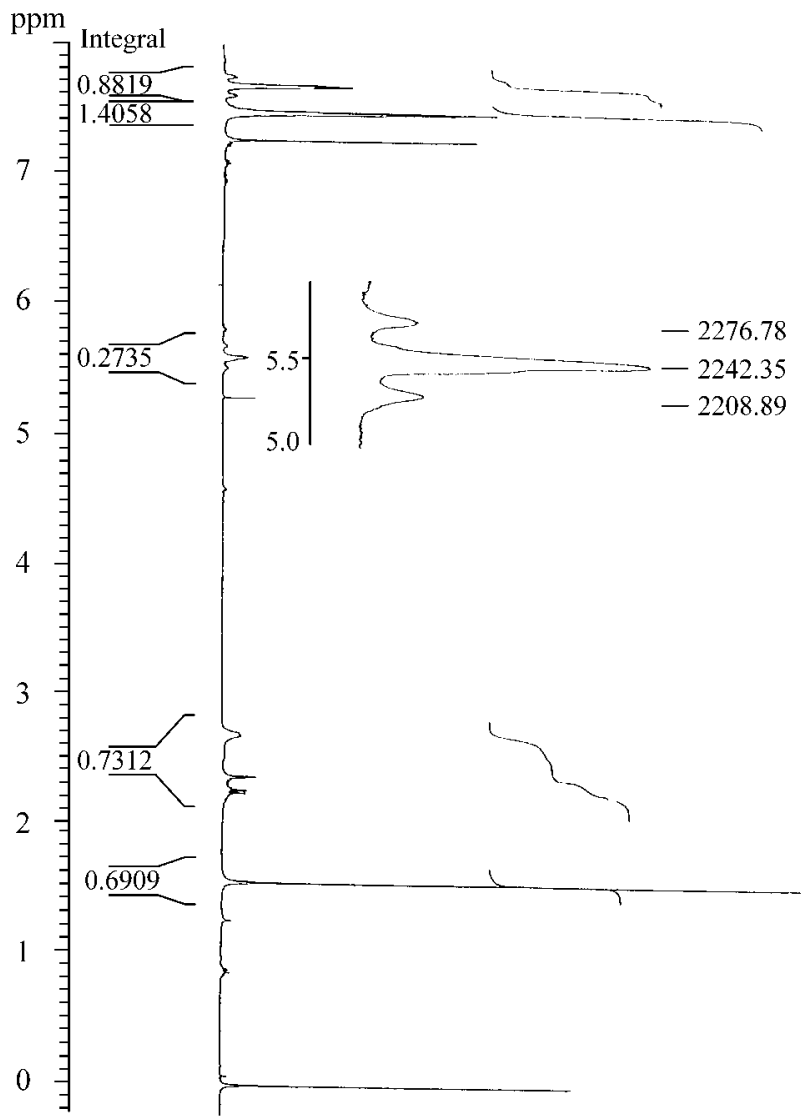

Figure 2. ${ }^{1} \mathrm{H}-\mathrm{NMR}$ spectrum $\left(400 \mathrm{MHz}, \mathrm{CDCl}_{3}\right)$ of complex $1 ;{ }^{2} \mathrm{JPt}-\mathrm{H}=$ $67.8 \mathrm{~Hz}$. Peaks at $\delta=1.55$ and 5.22 are due to water, present in the solvent and to $\mathrm{CH}_{2} \mathrm{Cl}_{2}$, respectively.

Table 2. ${ }^{2} \mathrm{JPt}-\mathrm{H}$ coupling constants, in Hz, of complexes 1 to 4 .

\begin{tabular}{lc}
\hline Complex & ${ }^{2} \mathrm{~J}_{\mathrm{Pt}-\mathrm{H}}$ \\
\hline $1^{\mathrm{a}}$ & $5.60\left(\mathrm{br},{ }^{2} \mathrm{~J}_{\mathrm{Pt}-\mathrm{H}}=67.89 \mathrm{~Hz}\right)$ \\
$2^{\mathrm{a}}$ & 5.50 and $5.37\left(\mathrm{~m},{ }^{2} \mathrm{~J}_{\mathrm{Pt}-\mathrm{H}}=58.49\right.$ and 54.14$)$ \\
$3^{\mathrm{a}}$ & $5.63\left(\mathrm{~s},{ }^{2} \mathrm{JPt}_{\mathrm{Pt}}=66.41 \mathrm{~Hz}\right)$ \\
$4^{\mathrm{b}}$ & $4.66\left(\mathrm{~s},{ }^{2} \mathrm{~J}_{\mathrm{Pt}-\mathrm{H}}=55.03 \mathrm{~Hz}\right)$ \\
\hline
\end{tabular}

${ }^{\mathrm{a}}$ Data obtained in $\mathrm{CDCl}_{3} .{ }^{\mathrm{b}}$ Data obtained in $\left(\mathrm{CD}_{3}\right)_{2} \mathrm{CO}$.

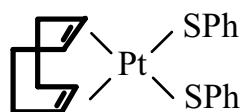

Complex 3

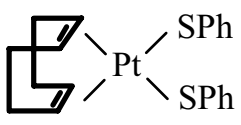

Complex 4

Figure 1. Proposed molecular structures for complexes 1 to 4 . 
such data in the literature. Also, complex $\mathbf{3}$ was reported as an intermediate but the literature states it could not be isolated. The ${ }^{2} \mathrm{~J}_{\mathrm{Pt}-\mathrm{H}}$ coupling constants for complex $\mathbf{1}$ and $\mathbf{2}$ are within the range observed for other Pt(IV)-Sn complexes ${ }^{7}$. In the ${ }^{13} \mathrm{C}$-NMR spectrum of complex $\mathbf{2}$, four resonances are observed for the carbons of the olefin and two resonances for the $\mathrm{CH}_{2}$ group. However, we were not able to determine the $\mathrm{J}_{\mathrm{Pt}-\mathrm{C}}$ coupling constants for complexes $\mathbf{1}$ and 2, as for complexes $\mathbf{3}$ and $\mathbf{4}$. Although the signals in the ${ }^{13} \mathrm{C}-\mathrm{NMR}$ were well defined, they were of little intensity which precluded the determination of this coupling constant.

We encountered solubility problems especially with complexes $\mathbf{1}$ and $\mathbf{2}$. In all cases an emulsion was obtained. Low solubility has been observed for other Pt(IV) complexes $^{2,7 a, 8}$. However, the low solubility was the factor that permitted us to isolate complexes $\mathbf{1}$ and $\mathbf{2}$. As pointed out by others, many $\mathrm{Pt}(\mathrm{IV})$ complexes are formed but they are rarely isolated because they have a tendency, in solution, to undergo rapid reductive elimination, yielding Pt(II) com-

Table 3. JPt-C, in Hz, of complexes 1 to 4.

\begin{tabular}{lc}
\hline Complex & $\mathbf{J}_{\mathrm{Pt}-\mathrm{C}}$ \\
\hline 1 & not observed \\
2 & not observed \\
$3^{\mathrm{a}}$ & $\mathrm{JPt}_{\mathrm{C}}=600.8 \mathrm{~Hz}$ \\
$4^{\mathrm{a}}$ & $\mathrm{J}_{\mathrm{Pt}-\mathrm{C}}=480 \mathrm{~Hz}$ \\
\hline
\end{tabular}

${ }^{\mathrm{a} D a t a}$ obtained in $\mathrm{CDCl}_{3}$. plexes, both soluble and insoluble ${ }^{9}$. This behavior could be observed in the present work. If complexes $\mathbf{1}$ to $\mathbf{4}$ were left for long periods of time $(>0.5 \mathrm{~h})$ in solution, a yellow insoluble solid precipitated on the bottom of the flask. In both the ${ }^{1} \mathrm{H}$ - and ${ }^{13} \mathrm{C}$-NMR spectra of the four solutions, small peaks at $\delta=4.60\left({ }^{2} \mathrm{~J}_{\mathrm{Pt}-\mathrm{H}}=71.8 \mathrm{~Hz}\right), 99.0,30.79$ could be observed. Complex 1 was the most soluble of the two heterobimetallic complexes, and for this reason we could obtain a ${ }^{119} \mathrm{Sn}-\mathrm{NMR}$ spectrum of this complex ${ }^{\#} .{ }^{195} \mathrm{Pt}-\mathrm{NMR}$ spectra could be obtained for both complexes, the values were $\delta=-3834.8$ and $\delta=-3653.05$ for complexes $\mathbf{1}$ and $\mathbf{2}$ respectively, and are in accordance with the fact that since complex 1 is surrounded by less electro-ndonating ligands, $\delta{ }^{195} \mathrm{Pt}$ is observed at higher field. These values are found at lower field as compared to the resonance found for heterobimetallic $\mathrm{Pt}(\mathrm{II})-\mathrm{Sn}$ complexes, e.g., trans-PtCl $\left(\mathrm{SnCl}_{3}\right)\left(\mathrm{PEt}_{3}\right)_{2}, \delta=-4790.0$ and trans $-\mathrm{Pt}\left(\mathrm{SnCl}_{3}\right)_{2}\left(\mathrm{PEt}_{3}\right)_{2}$, $\delta=-5093.0^{10}$. The data obtained from the Mössbauer spectra were indicative of a tetrahedral environment around the tin atom as well as being bonded to another metal. Table 4 gives Mössbauer parameters for other Pt(IV)-Sn compounds for comparison. For all the complexes a singlet could be observed around $\delta=5.2$, in the ${ }^{1} \mathrm{H}-\mathrm{NMR}$ spectrum, that was attributed to the hydrogens of the solvent $\mathrm{CH}_{2} \mathrm{Cl}_{2}$. The structures proposed for the complexes, shown in Fig. 1, were based also on the elemental analysis and atomic absorption.

Table 4. Mössbauer parameters for some Pt-Sn complexes.

\begin{tabular}{lccc}
\hline Complex & $\delta(\mathrm{mm} / \mathrm{s})$ & $\Delta(\mathrm{mm} / \mathrm{s})$ & Ref. \\
\hline $\mathrm{CODPt}(\mathrm{Cl})(\mathrm{SPh})_{2} \mathrm{Sn}(\mathrm{Ph})_{3}$ & 1.34 & 2.54 & this work \\
$\mathrm{CODPt}(\mathrm{Cl})_{2}(\mathrm{SPh}) \mathrm{Sn}(\mathrm{Ph})_{3}$ & 1.44 & 2.44 & this work \\
trans $-\left(\mathrm{Ph}_{3} \mathrm{P}\right)_{2} \mathrm{Pt}(\mathrm{Cl}) \mathrm{SnCl}_{3}$ & 1.84 & 2.07 & 13 \\
$\left(\mathrm{Ph}_{3} \mathrm{P}\right)_{2} \mathrm{PtCl}_{2}\left(\mathrm{SnCl}_{3}\right)_{2}$ & 1.69 & 1.94 & 13 \\
trans $-\left(\mathrm{Et}_{3} \mathrm{P}\right)_{2} \mathrm{Pt}(\mathrm{H}) \mathrm{SnCl}_{3}$ & 2.02 & 1.89 & 13 \\
cis- $\left(\mathrm{Me}_{4} \mathrm{~N}\right)_{2}\left[\mathrm{PtCl}_{2}\left(\mathrm{SnCl}_{3}\right)_{2}\right]$ & 1.70 & 2.11 & 14 \\
cis- $\left(\mathrm{Ph}_{4} \mathrm{As}\right)_{2}\left[\mathrm{PtCl}_{2}\left(\mathrm{SnCl}_{3}\right)_{2}\right]$ & 1.67 & 2.18 & 14 \\
\end{tabular}

$$
\mathrm{CODPtCl}_{2}+2(\mathrm{Ph})_{3} \mathrm{Sn}(\mathrm{SPh}) \longrightarrow{ }_{\mathrm{SPh}}^{\longrightarrow}
$$

Complex 1

\footnotetext{
${ }^{\#}$ The natural abundance of ${ }^{119} \mathrm{Sn}$ and ${ }^{117} \mathrm{Sn}$ isotopes are respectivelly $8.58 \%$ and $7.61 \%$. This low abundance requires longer periods of time toobatin a good spectrum.
} 


\section{Mechanistic Studies}

The mechanism that is generally proposed for reactions between Pt(II) and $\mathrm{Sn}(\mathrm{IV})$ compounds leading to heterobimetallic Pt(IV)-Sn complexes is the oxidative addition of tin chlorides to the platinum nucleophilic center ${ }^{7 \mathrm{a}, 7 \mathrm{~b}, 11}$. The formation of complex 1 could be explained perfectly using such a mechanism, as represented in Eqs. 1 and 2.

First, there ought to be a nucleophilic displacement of halide by the thiolate, as shown in Eq. 1, followed by the oxidative addition of $(\mathrm{Ph})_{3} \mathrm{SnCl}$, yielding complex 1, Eq. 2 . However, when the reaction shown in Eq. 2 was performed independently using first, stoichiometric quantities and then excess of tin chloride both at room temperature or under reflux, no heterobimetallic complex was obtained. Reaction between $\mathrm{CODPtCl}_{2}$ and $(\mathrm{Ph})_{2} \mathrm{Sn}(\mathrm{SPh})_{2}$ yielded only $\operatorname{CODPt}(\mathrm{SPh})_{2}$, as a platinum containg product; no heterobimetallic complex was formed in the reaction, despite the reaction being more favourable as $\mathrm{Ph}_{2} \mathrm{SnCl}_{2}$ is a better electrophile than $\mathrm{Ph}_{3} \mathrm{SnCl}_{2}$. The reaction shown in Eq. 3, also did not yield any heterobimetallic complex:

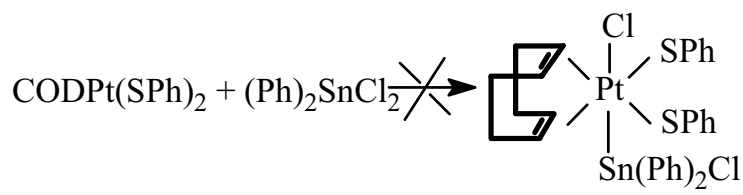

According to the suggested mechanism we could not explain the formation of complex $\mathbf{2}$. These facts suggested to us that the mechanism for the reactions decribed here must involve oxidative additions of the tin thiolate instead of the tin chloride. The proposed mechanism for the formation of complex 1 is represented in Eqs. 4 and 5 as follows.

First, it must involve the nucleophilic displacement on only one metal-chloride bond by the thiolate, yielding complex $\mathbf{3}$ which is a likely intermediate in this reaction. The oxidative addition of $(\mathrm{Ph})_{3} \mathrm{Sn}(\mathrm{SPh})$ to the intermediate yields complex 1 . The oxidative addition of the tin thiolate explains the formation of complex 2, as represented in Eq. 6. It involves the direct oxidative addition of the tin thiolate to $\mathrm{CODPtCl}_{2}$.

Thus it is possible to explain why reaction between $\mathrm{CODPtCl}_{2}$ and $(\mathrm{Ph})_{2} \mathrm{Sn}(\mathrm{SPh})_{2}$ did not yield a product due

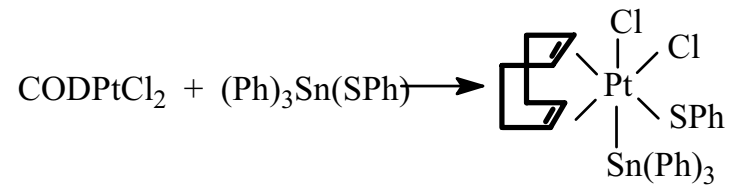

Complex 2

to the oxidative addtion reaction. $\mathrm{As}(\mathrm{Ph})_{2} \mathrm{Sn}(\mathrm{SPh})_{2}$ is a worse eletrophile than $(\mathrm{Ph})_{3} \mathrm{Sn}(\mathrm{SPh})$, it does not add oxidatively to the platinum nucleophilic center. Also, the reaction represented in Eq. 2 does not occur because, although $(\mathrm{Ph})_{3} \mathrm{Sn}(\mathrm{SPh})$ is the best eletrophile, $\mathrm{CODPt}(\mathrm{SPh})_{2}$ is a poor nucleophile as compared to $\mathrm{CODPtCl}_{2}$.

\section{Conclusions}

The reactions described here involve a rare type of oxidative addition of tin thiolates. In fact just one case has been described recently in the literature and according to the authors ${ }^{7 \mathrm{c}}$ and to the present work these oxidative additions are cis instead of the trans type of oxidative addtions of tin chlorides. The present work allowed us to conclude that reactions between platinum compounds, a late transition metal, with tin thiolates do not cleave C-S bonds but a new route was found for obtaining $\mathrm{Pt}(\mathrm{IV})$-Sn heterobimetallic complexes. Pt(IV)-Sn heterobimetallic complexes are known to participate in many homogeneous catalytic processes, especially in the hydroformylation of olefines ${ }^{12}$.

\section{Acknowledgments}

To the agencies that support our work: FAPEMIG, CNPq/PADCT, FINEP and PRPq. To Prof. Carlos Alberto Lombardi Filgueiras for valuable suggestions and to Wagner Magno Teles for his help with the synthesis of $\mathrm{CODPtCl}_{2}$.

\section{References}

1. Results to be published

2. Osakada, Kohtaro; Kawagushi, Yasuharu; Yamamoto, Takakazu.Organometallics 1995, 14, 4542.

3. Drew, D.; Doyle, J.R. Inorg. Synth. 1972, 13, 47.

4. Duarte, Paulo Henrique; Aguiar-Junior, Silvestre Rabello; Silva, Rosalice M.; Guimarães, Beatriz G.; Speziali, Nivaldo L. Química Nova 1995, 18, 329.
$\mathrm{CODPtCl}_{2}+2(\mathrm{Ph})_{3} \mathrm{Sn}(\mathrm{SPh}) \longrightarrow \mathrm{CODPt}^{\prime}{ }_{\mathrm{Cl}}^{\mathrm{SPh}}+(\mathrm{Ph})_{3} \mathrm{Sn}(\mathrm{SPh})+(\mathrm{Ph})_{3} \mathrm{SnCl}$

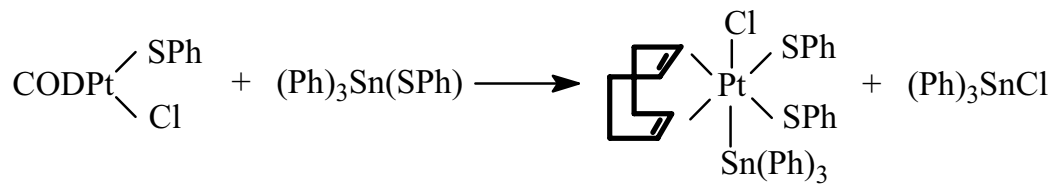

Complex 1 
5. Nakamoto, Kazuo. In Infrared and Raman Spectra of Inorganic and Coordination Compounds, 4th Ed. John Wiley \& Sons 1986, p. 342.

6. a) Colin, Eaborna; Pidcock, A.; Steele, B.R. J.Chem. Soc. Dalton 1976, 767; b) Alcock, N.W.; Nelson, J.H. J.Chem. Soc. Dalton 1982, 2415.

7.a) Levy, C.J.; Vittal, J.J.; Puddephatt, R.J. Organometallics 1996, 15, 35; b) Ibid, 2108; c) Rendina, L.M.; Vitta, J.J.; Puddephatt, R. J. Orgnometallics 1996, $15,1749$.

8. a) Clemmit, A.F.; Glockling, F. J. Chem. Soc. A 1971, 1164; b) Glockling, F.; Pollock, R.J. Ivan. J. Chem.Soc. Dalton 1975, 497.

9. Eaborn, C.; Pidcock, A.; Steele, B.R. J. Chem. Soc. Dalton 1975, 975.
10. a) Pregosin, P.S.; Sze, S.N. Helvetica Chimica Acta 1978, 61(5), 1848; b) Starzewski, Karl-H.A.O.; Pregosin, P.S. Angew Chem. Int. Ed. Engl. 1980, 19, 316; c) Ursini, C.V. Química Nova 1997, 20, 72.

11. Kuyper, Jan. Inorg. Chem. 1977, 16, 2171.

12. a) McKay, K.M.; Nicholson, B.K. In Comprehensive Organometallic Chemistry; Wilkinson, G.; Stone, F.G.A.; Abel, E.W.; Eds.; Pergamom: Oxford, 1982; Vol.6; b) Kubota, M. Inorg. Chem. 1990, 29, 574.

13. Parish, R.V.; Rowbottom, P.J. J.Chem.Soc. Dalton 1973, 37.

14. Parish, R.V. Coord. Chem. Rev. 1982, 42, 1. 